\title{
ELECTROCHEMICAL SYNTHESIS OF PEROXYACETIC ACID ON Pt/PtO AND $\mathrm{PbO}_{2}$ ANODES
}

\author{
Tetiana Bilous ${ }^{1}{ }^{凶}$, Alena Tulskaya ${ }^{1}$, Igor Ryshchenko ${ }^{1}$, \\ Issam Chahine ${ }^{1}$, Volodymyr Bairachnyi ${ }^{1}$
}

https://doi.org/10.23939/chcht14.02.135

\begin{abstract}
The kinetics of anodic processes on $\mathrm{Pt} / \mathrm{PtO}$ and $\mathrm{PbO}_{2}$ anodes has been studied in water solutions of acetic acid. The addition of sulfuric acid has a catalytic effect in the electrochemical synthesis of peroxyacetic acid. The choice of promoters of peroxide-particles formation has been proved. $\Gamma, \mathrm{Cl}^{-}$(current efficiency is $1.2-1.5 \%$ ) particles have been defined as the most effective for platinum anode and $\mathrm{I}^{-}, \mathrm{F}^{-}$(current efficiency is $0.50-0.55 \%$ ) have been defined as the most effective for lead-dioxide anode.
\end{abstract}

Keywords: peroxyacetic acid, acetic acid, platinum anode, lead-dioxide anode, promoter, peroxide particles.

\section{Introduction}

Peroxyacetic acid (PAA) is a strong disinfectant with a wide spectrum of antimicrobial activity. It has been widely used in medical and hygiene fields, and disinfection of wastewater. Recently, PAA emerges as an alternative to a conventional chlorine containing chemicals in the effort to develop a more environmentally friendly bleaching process in pulping and paper-making industry. It is also an excellent active reagent for epoxidation of unsaturated triglycerides for obtaining low cost plasticizers with good performance from natural and renewable sources. The wide use of PAA is limited by its high price.

PAA is produced on an industrial scale by a chemical synthesis through the interaction of concentrated acetic acid with the concentrated peroxide of hydrogen $(60-80 \%)$ with an application of acid catalyst. The chemical formation of PAA is performed with significant losses of hydrogen peroxide. The output product requires specific storage conditions [1-6].

Electrochemical methods of PAA synthesis are divided into two directions: i) production of PAA by the cathodic generation of hydrogen peroxide with the

\footnotetext{
${ }^{1}$ National Technical University "Kharkiv Polytechnic Institute",

2, Kyrpychova St., 61002 Kharkiv, Ukraine

\beloustany@ukr.net

(C) Bilous T., Tulskaya A., Ryshchenko I., Chahine I., Bairachnyi V., 2020
}

presence of acetic acid [7, 8]; ii) production of PAA through the anodic oxidation [9-14]. The advantages of electrochemical synthesis are production of PAA directly in situ and synthesis of diluted PAA and acetic acid. However, the concentration of PAA is lower comparing to the chemical synthesis, which can be defined as a disadvantage.

The intensification of anodic process through the application of promoters of peroxide-particles formation is an actual issue [12-14]. The promoters should have an influence on the selectivity of anodic process and prevent the oxygen release. In this case the effect of thiocyanate$[15,16]$ and halogen ions on the kinetics of anodic processes in acetic acid solutions has been carefully studied.

The aims of this research are to study the impact of anodic material on the kinetics of anodic processes in water acetic solutions, to study the influence of electrically conductive admixture on the kinetics of anodic processes in water acetic solutions and to justify the promoters of peroxide-particles formation.

\section{Experimental}

Electrolytes were prepared using the chemically pure acetic and sulfuric acid.

The volt-ampere curves were obtained with the potentiostat P-45X. Scan sweep is $10 \mathrm{mV} / \mathrm{s}$. Polarization research was performed in the electrochemical cell within the temperature range of 284-287 K. There are two types of anodes: i) platinum plate with an active surface about $1.13 \mathrm{~cm}^{2}$; ii) titanium current lead with $\mathrm{RuO}_{2}$ sublayer and covered by $\mathrm{PbO}_{2}$ with an active surface about $1.1 \mathrm{~cm}^{2}$. Side and back surfaces of anodes were isolated. Auxiliary electrode was made of platinum. The silver chloride electrode was applied as the reference one.

Electrolysis was performed in the cell with the separation of anodic and cathode space by a polyvinyl chloride membrane. The width of anolyte layer is $10 \mathrm{~mm}$, temperature is $278-281 \mathrm{~K}$. The temperature was controlled by a cooling chamber. There were two types of 
anodes: i) platinum plate with an active surface of about $17.5 \mathrm{~cm}^{2}$; ii) titanium current lead with $\mathrm{RuO}_{2}$ sublayer covered by $\mathrm{PbO}_{2}$ with an active surface of about $17.8 \mathrm{~cm}^{2}$. Auxiliary electrode was made of $12 \mathrm{Cr} 18 \mathrm{Ni10Ti}$ steel. A stabilized power supply unit B5-46 has been applied.

The concentration of PAA in the anolyte has been defined by an iodometry [9].

\section{Results and Discussion}

The direction of anodic processes in the acetic solution depends on the numerous conditions of the process. The largest impact has $\mathrm{pH}$ of electrolyte, anodic material, anodic potential and temperature [7-14].

Electrochemical synthesis of PAA is the result of oxidation of acetic acid molecules:

$$
\begin{gathered}
\mathrm{CH}_{3} \mathrm{COOH}+\mathrm{H}_{2} \mathrm{O}=\mathrm{CH}_{3} \mathrm{COOOH}+2 \mathrm{H}^{+}+2 \mathrm{e}^{-}, \\
\mathrm{E}_{\mathrm{CH}_{3} \mathrm{COOH} / \mathrm{CH}_{3} \mathrm{COOOH}}^{0}=1.8186 \mathrm{~V}
\end{gathered}
$$

To perform the electrochemical synthesis of PAA we apply water solutions of acetic acid with the concentration in the range of $0.5-9.0 \mathrm{~mol} / \mathrm{dm}^{3}$. In the water solutions of acetic acid the oxidation of water is combined with an anodic process (1):

$$
\begin{gathered}
2 \mathrm{H}_{2} \mathrm{O}=\mathrm{O}_{2}+4 \mathrm{H}^{+}+4 \mathrm{e}^{-}, E_{\mathrm{H}_{2} \mathrm{O} / \mathrm{O}_{2}}^{0}=1.228 \mathrm{~V} \\
2 \mathrm{H}_{2} \mathrm{O}=\mathrm{H}_{2} \mathrm{O}_{2}+2 \mathrm{H}^{+}+2 \mathrm{e}^{-}, \mathrm{E}_{\mathrm{H}_{2} \mathrm{O} / \mathrm{H}_{2} \mathrm{O}_{2}}^{0}=1.776 \mathrm{~V}
\end{gathered}
$$

Electrochemical synthesis of hydrogen peroxide can not be performed at the temperatures above 290-295 K.

To achieve the required anodic potentials for processes (1) and (3), we should apply the material with the

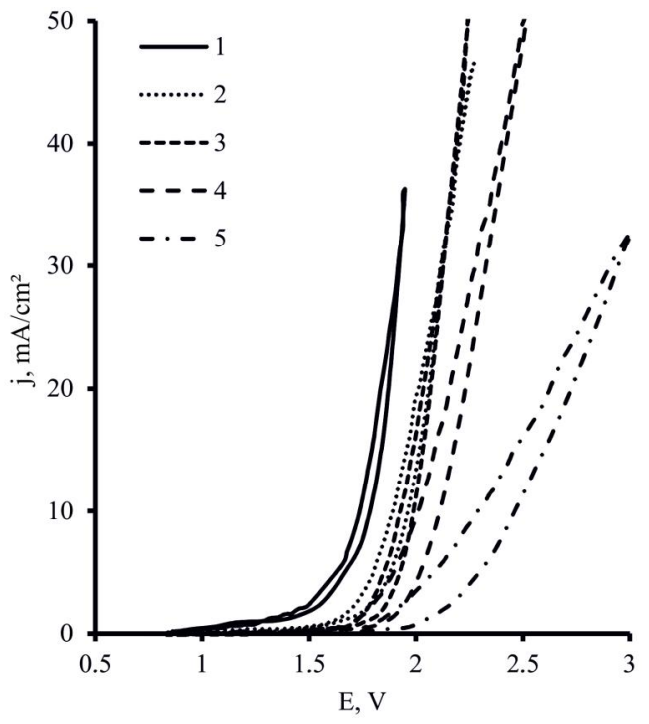

a) high oxygen overvoltage. Platinum and lead-dioxide anodes have been used to study the kinetics of anodic process in the water acetic solution.

Potentiodynamic curves in the water acetic solution for $\mathrm{Pt} / \mathrm{PtO}$ (Fig. 1a) and $\mathrm{PbO}_{2}$ (Fig. 1b) are slightly different.

The increase of the acetic acid concentration leads to the significant shift of potential into the positive area on the $\mathrm{Pt} / \mathrm{PtO}$ anode. It can be explained by the influence of acetic acid concentration on the adsorption on the $\mathrm{Pt} / \mathrm{PtO}$ surface. Acetic acid concentration does not make any influence on the electrochemical process on $\mathrm{PbO}_{2}$ anodes at the concentrations from 1 to $6 \mathrm{~mol} / \mathrm{dm}^{3}$.

The current rise for acetic acid $\left(C=0.5 \mathrm{~mol} / \mathrm{dm}^{3}\right)$ begins at 1.0-1.1 V (Fig. 1a). These values are correlated with an oxygen volume. With further increase in anodic potential the formation of $\mathrm{H}_{2} \mathrm{O}_{2}$ and PAA begins. The presence of $\mathrm{H}_{2} \mathrm{O}_{2}$ and PAA has been proved by results of iodometric titration.

The current rise for concentrated acetic acid $\left(C=1-9 \mathrm{~mol} / \mathrm{dm}^{3}\right)$ starts at $1.6-1.8 \mathrm{~V}$ (Fig. 1a) and is combined with the formation of $\mathrm{H}_{2} \mathrm{O}_{2}$ and PAA. It is also well-known that $\mathrm{Pt} / \mathrm{PtO}$ anodes are catalysts for hydrogen peroxide destruction [12-14]. Electrochemical synthesis of PAA on the $\mathrm{Pt} / \mathrm{PtO}$ anode proceeds through the following stages:

$$
\begin{gathered}
\mathrm{Pt} / \mathrm{PtO}+\mathrm{H}_{2} \mathrm{O} \rightarrow \mathrm{Pt} / \mathrm{PtO}(\mathrm{OH} \cdot)+\mathrm{H}^{+}+\mathrm{e}^{-} \\
\mathrm{Pt} / \mathrm{PtO}(\mathrm{OH} \cdot)+\mathrm{CH}_{3} \mathrm{COOH} \rightarrow \\
\mathrm{I} \rightarrow \mathrm{Pt} / \mathrm{PtO}+\mathrm{CH}_{3} \mathrm{COOOH}+\mathrm{H}^{+}+\mathrm{e}^{-}
\end{gathered}
$$

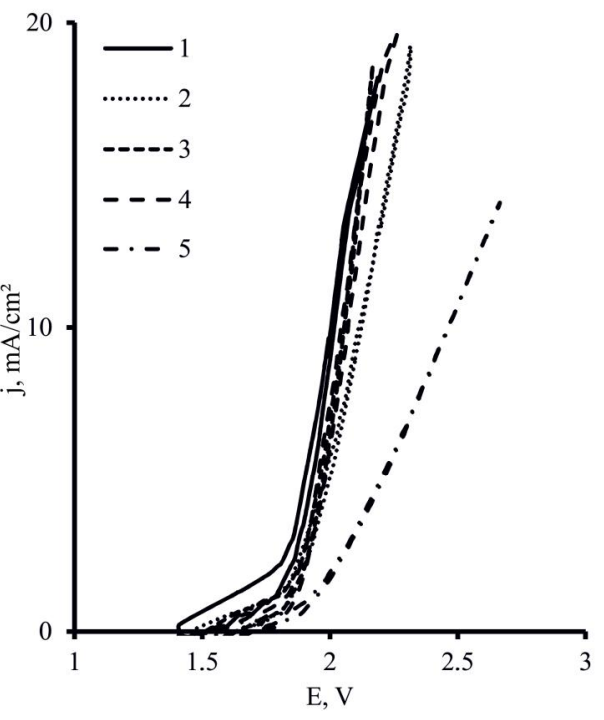

b)

Fig. 1. Anodic polarization curves on $\mathrm{Pt} / \mathrm{PtO}$ (a) and $\mathrm{PbO}_{2}$ (b) in the water acetic solution, $\mathrm{mol} / \mathrm{dm}^{3}: 0.5(1) ; 1$ (2); 3 (3); 6 (4) and 9 (5) 
The current rise on $\mathrm{PbO}_{2}$ anode surface in 0.5 $9.0 \mathrm{~mol} / \mathrm{dm}^{3}$ acetic solution starts at $1.4-1.5 \mathrm{~V}$ and higher (Fig. 1b) and is accompanied by the oxygen release. The rise of anodic potentials from $1.8-1.9 \mathrm{~V}$ and higher leads to the formation of $\mathrm{H}_{2} \mathrm{O}_{2}$ and PAA. Concentration of acetic acid on $\mathrm{PbO}_{2}$ surface does not make a significant influence on $\mathrm{OH}$-adsorption (Fig. 1b). Considering this, it should be concluded that the adsorption of acetic molecules on the surface of $\mathrm{PbO}_{2}$ anode is quite weak. Therefore, the radical $\mathrm{OH} \cdot$ particle can be formed on $\mathrm{PbO}_{2}$ surface and involved into PAA formation:

$$
\begin{gathered}
\mathrm{H}_{2} \mathrm{O} \rightarrow \mathrm{OH} \cdot+\mathrm{H}^{+}+\mathrm{e}^{-} \\
\mathrm{OH} \cdot+\mathrm{CH}_{3} \mathrm{COOH} \rightarrow \mathrm{CH}_{3} \mathrm{COOOH}+\mathrm{H}^{+}+\mathrm{e}^{-}
\end{gathered}
$$

At the potentials higher than $2.2-2.3 \mathrm{~V}$ the following reactions can be performed: the Kolbe reaction; reactions of anodic displacement and addition; destructive oxidation of acetic acid [12, 15, 16]. Electrochemical synthesis of PAA is impractical in these conditions. Synthesis of PAA should be performed in the range of anodic current density $50-150 \mathrm{~A} / \mathrm{m}^{2}$.

The further research was conducted with the application of water solution of acetic acid $\left(C=3 \mathrm{~mol} / \mathrm{dm}^{3}\right)$. The specific conductivity of water acetic solution is $\kappa=1.53 \cdot 10^{-3} \mathrm{Sm} / \mathrm{cm}[14]$. Application of water solution without conductive admixtures is impractical. Sulfuric acid with concentration of $0.5 \mathrm{~mol} / \mathrm{dm}^{3}$ was chosen as a conductive admixture and was added into the acetic solution. According to the results of the research, electrochemical synthesis of PAA should be performed in the range of current densities from 500 to $1500 \mathrm{~A} / \mathrm{m}^{2}$, where the maximal current efficiency can be reached.
Using the $\mathrm{PbO}_{2}$ anode for PAA synthesis was more effective comparing to $\mathrm{Pt} / \mathrm{PtO}$. The efficiency was estimated by the current efficiency value which is higher on the $\mathrm{PbO}_{2}$ anodes.

Addition of the sulphuric acid makes the catalytic effect in the electrochemical synthesis of PAA.

The study of adsorption of acetic acid on $\mathrm{Pt} / \mathrm{PtO}$ and $\mathrm{PbO}_{2}$ anodic surface was conducted using the water acetic solution $\left(C=10^{-2} \mathrm{~mol} / \mathrm{dm}^{3}\right)$ with the addition of $10^{-2} \mathrm{~mol} / \mathrm{dm}^{3} \mathrm{H}_{2} \mathrm{SO}_{4}$. The adsorption of acetic molecules calculated taking in account the anode geometry was $(2-8) \cdot 10^{-6} \mathrm{~mol} / \mathrm{cm}^{2}$ for $\mathrm{Pt} / \mathrm{PtO}$ and $(3-7) \cdot 10^{-8} \mathrm{~mol} / \mathrm{cm}^{2}$ for $\mathrm{PbO}_{2}$. The higher adsorption on platinum surface proves the mechanism (4)-(5), and the low adsorption on the $\mathrm{PbO}_{2}$ surface with the value of current efficiency of PAA ( 0.12 and $0.36 \%$ for $\mathrm{Pt} / \mathrm{PtO}$ and $\mathrm{PbO}_{2}$, respectively) correlated with the mechanism (6)-(7).

Anodic process of PAA formation can be intensified by applying the peroxide-particles as promoters in the electrolyte. Polarization curves were obtained in $3 \mathrm{~mol} / \mathrm{dm}^{3} \mathrm{CH}_{3} \mathrm{COOH}+0.5 \mathrm{~mol} / \mathrm{dm}^{3} \mathrm{H}_{2} \mathrm{SO}_{4}$ with the addition of $\mathrm{CNS}^{-}, \mathrm{I}^{-}, \mathrm{Cl}^{-}, \mathrm{Br}^{-}, \mathrm{F}^{-}$. Ions were added with the appropriate salts of alkali metals. Addition of $\mathrm{CNS}^{-}, \mathrm{I}^{-}, \mathrm{Cl}^{-}, \mathrm{Br}^{-}, \mathrm{F}^{-}$leads to braking the combined anodic process of oxygen release (Table).

The most effective additions for $\mathrm{Pt} / \mathrm{PtO}$ anode are $\mathrm{I}^{-}, \mathrm{Cl}^{-}$(current efficiency is $1.2-1.5 \%$ ); for $\mathrm{PbO}_{2}$ anode addition of $\Gamma, F$ (current efficiency is $0.50-0.55 \%$ ). Addition of $\mathrm{CNS}^{-}$was defined as impractical.

The concentration of PAA, obtained by electrochemical synthesis correlates with the concentration of PAA in the disinfectant solution: in medicine $(0.1 \%)$, at poultry farms $(0.02-0.03 \%)$, in dairy industry $(0.015-0.025 \%)$.

Table

\begin{tabular}{|c|c|c|c|c|c|c|c|c|}
\hline \multirow[b]{2}{*}{$\begin{array}{l}\text { Electrolyte } \\
\text { composition, } \\
\text { mol/ } / \mathrm{dm}^{3}\end{array}$} & \multicolumn{4}{|c|}{$\mathrm{Pt} / \mathrm{PtO}$} & \multicolumn{4}{|c|}{$\mathrm{PbO}_{2}$} \\
\hline & $\begin{array}{l}\text { Current } \\
\text { density } j \text {, } \\
\mathrm{mA} / \mathrm{cm}^{2}\end{array}$ & $\begin{array}{c}\text { Amount of } \\
\text { electricity } \\
Q, \mathrm{~A} \cdot \mathrm{h}\end{array}$ & $\begin{array}{c}\text { Current } \\
\text { efficiency for } \\
\text { PAA, \% }\end{array}$ & $\begin{array}{c}C_{\mathrm{PAA}}, \\
\%\end{array}$ & $\begin{array}{r}\text { Current } \\
\text { density } j, \\
\mathrm{~mA} / \mathrm{cm}^{2}\end{array}$ & $\begin{array}{c}\text { Amount of } \\
\text { electricity } Q \text {, } \\
\text { A.h }\end{array}$ & $\begin{array}{c}\text { Current } \\
\text { efficiency for } \\
\text { PAA, \% }\end{array}$ & $\begin{array}{c}C_{\mathrm{PAA}}, \\
\%\end{array}$ \\
\hline $\begin{array}{l}\text { Original solution } \\
(\mathrm{OS}): \mathrm{CH}_{3} \mathrm{COOH}-3 ; \\
\mathrm{H}_{2} \mathrm{SO}_{4}-0.5\end{array}$ & 100 & 2.6 & 0.12 & 0.01 & 100 & 2.7 & 0.36 & 0.03 \\
\hline $\mathrm{OS}+0.001 \mathrm{NH}_{4} \mathrm{CNS}$ & 160 & 2.6 & 0.12 & 0.01 & 100 & 2.7 & 0.27 & 0.02 \\
\hline $\mathrm{OS}+0.001 \mathrm{KI}$ & 100 & 2.6 & 1.24 & 0.09 & 100 & 2.7 & 0.53 & 0.04 \\
\hline $\mathrm{OS}+0.001 \mathrm{KCl}$ & 100 & 2.6 & 1.46 & 0.10 & 100 & 2.7 & 0.42 & 0.03 \\
\hline $\mathrm{OS}+0.001 \mathrm{KBr}$ & 100 & 2.6 & 1.19 & 0.08 & 100 & 2.7 & 0.38 & 0.03 \\
\hline $\mathrm{OS}+0.001 \mathrm{KF}$ & - & $\begin{array}{l}- \\
-\end{array}$ & $\begin{array}{lllll}- & \end{array}$ & - & 100 & 2.7 & 0.49 & 0.04 \\
\hline
\end{tabular}

The results of electrochemical synthesis of PAA on Pt/PtO and $\mathrm{PbO}_{2}$

\section{Conclusions}

The possibility of electrochemical synthesis of PAA, which can be applied in different branches of industry, has been shown. Stages of electrochemical for- mation of $\mathrm{PAA}$ on $\mathrm{Pt} / \mathrm{PtO}$ and $\mathrm{PbO}_{2}$ anodic surfaces have been performed. Acetic acid molecules are oxidized through the reaction with radical $\mathrm{OH}$ particles on the anodic surface. It has been shown that the addition of $0.5 \mathrm{~mol} / \mathrm{dm}^{3}$ sulfuric acid makes the catalytic effect in the 
electrochemical synthesis of PAA. Application of $\mathrm{PbO}_{2}$ in anodes is much more effective comparing to $\mathrm{Pt} / \mathrm{PtO}$. The range of current densities $500-1500 \mathrm{~A} / \mathrm{m}^{2}$ has been defined as the most expedient in the electrochemical synthesis of PAA. Addition of $\mathrm{CNS}^{-}, \Gamma, \mathrm{Cl}^{-}, \mathrm{Br}^{-}, \mathrm{F}^{-}$ions brakes the combined anodic process which is oxygen release. For the $\mathrm{Pt} / \mathrm{PtO}$ anode the most effective additions are $\Gamma, \mathrm{Cl}^{-}$(current efficiency is $1.2-1.5 \%$ ); for $\mathrm{PbO}_{2}$ anode $-\mathrm{I}^{-}, \mathrm{F}^{-}$(current efficiency is $0.50-0.55 \%$ ). Addition of $\mathrm{CNS}^{-}$is impractical.

\section{References}

[1] Dul'neva L., Moskvin A.: Russ. J. Gen. Chem., 2005, 75, 1125. https://doi.org/10.1007/s11176-005-0378-8

[2] Zhao X., Zhang T., Zhou Y., Liu D.: J. Mol. Catal. A, 2007, 271, 246. https://doi.org/10.1016/j.molcata.2007.03.012

[3] Zhao X., Cheng K., Hao J., Liu D.: J. Mol. Catal. A, 2008, 284, 58. https://doi.org/10.1016/j.molcata.2008.01.003

[4] Zhao X., Zhang T., Zhou Y., Liu D.: Chinese J. Process Eng., $2008,8,35$.

[5] Sun X., Zhao X., Du W., Liu D.: Chinese J. Chem. Eng., 2011, 19, 964. https://doi.org/10.1016/S1004-9541(11)60078-5

[6] Zhang T., Luo J., Chuang K., Zhong L.: Chinese J. Chem. Eng., 2007, 15, 320. https://doi.org/10.1016/S1004-9541(07)60087-1

[7] Moraleda I., Llanos J., Sáez C. et al.: Electrochem. Commun., 2016, 73, 1. https://doi.org/10.1016/j.elecom.2016.10.010

[8] Saha M., Denggerile A., Nishiki Y. et al.: Electrochem. Commun., 2003, 5, 445. https://doi.org/10.1016/S1388-

2481(03)00097-3

[9] Cotillas S., Sánchez-Carretero A., Cañizares P. et al.: Ind. Eng. Chem. Res., 2011, 50, 10889. https://doi.org/10.1021/ie2009422

[10] Ruiz-Ruiz E., Meas Y., Ortega-Borges R., Baizabal J.: Surf.

Eng. Appl. Electrochem., 2014, 50, 478.

https://doi.org/10.3103/S106837551406009X
[11] Cañizares P., Sáez C., Sánchez-Carretero A., Rodrigo M.: J. Appl. Electrochem., 2009, 39, 2143. https://doi.org/10.1007/s10800009-9792-7

[12] Bilous T., Tulsky G.: Kinetics of Anodic Processes in Acetic Acid Solutions. [in:] Barsukov V. (Ed.), Promising Materials and Processes in Technical Electrochemistry. KNUTD, Kyiv 2016, 244248.

[13] Bilous T., Tulskaya A., Matrunchyk O.: The Choice of Anode Material for the Electrochemical Synthesis of Peroxyacetic Acid. [in:] Barsukov V. (Ed.), Promising Materials and Processes in Applied Electrochemistry. KNUTD, Kyiv 2017, 230-234.

[14] Bilous T., Tulsky G., Korohodska A., Podustov M.: Visnyk NTU “KhPI", 2017, 48, 24.

[15] Khidirov Sh.: Russ. J. Electrochem., 1992, 2, 158.

[16] Khidirov Sh., Khibiev Kh.: Russ. J. Electrochem., 2005, 11, 1176. https://doi.org/10.1007/s11175-005-0198-5

Received: May 16, 2018 / Revised: July 09, 2018 / Accepted: November 13, 2018

\section{ЕЛЕКТРОХІМІЧНИЙ СИНТЕЗ ПЕРОКСИОЦТОВОЇ КИСЛОТИ НА Рt/PtO ТА $\mathrm{PbO}_{2}$ АНОДАХ}

Анотація. Вивчена кінетика анодних прочесів на $\mathrm{Pt} / \mathrm{PtO}$ та $\mathrm{PbO}_{2}$ анодах у водних розчинах оцтової кислоти. Встановлено, щуо додавання сульфатної кислоти має каталітичний ефект в електрохімічному синтезі пероксиоцтовоі кислоти. Обтрунтовано вибір промоторів утворення пероксичастинок. Виявлено, щуо I, Cl (вихід за струмом 1.2-1.5\%) частинки є найбільш ефективними для платинового аноду та $\Gamma, F^{-}$(вихід за струмом 0.50-0.55\%) - найбільш ефективні для диоксид свинщевого аноду.

Ключові слова: пероксиоцтова кислота, оцтова кислота, платиновий анод, диоксид свинцевий анод, промотор, перокси-частинки. 